\title{
Comparison of nonlinear models in the description of carbon mineralization in litter soil
}

Edilson Marcelino Silva ${ }^{1}$

Ariana Campos Frühauf ${ }^{2}$

Sérgio Alberto Jane 3

Édipo Menezes da Silva 4

Joel Augusto Muniz ${ }^{5}$

Tales Jesus Fernandes ${ }^{6}$

\section{Abstract}

Litter is an important source of nutrients for trees and can improve the quality of degraded soils. The objective of this study was to describe the dynamics of carbon mineralization in litter soils using nonlinear models, estimating half-life times. Soil carbon mineralization under three types of forest cover was evaluated: Atlantic forest fragment (capoeira), Acacia auriculiformis trees (acacia), and Mimosa caesalpiniifolia (sabiá) from a reforested area with a history of degradation. Twelve measurements of the mineralized carbon were made up to 222 days after the beginning of the incubation of litter soils. Stanford and Smith, Juma, and Cabrera models were fitted by the least squares method using the Gauss-Newton algorithm in the R software. The Stanford and Smith model was more appropriate in describing all treatments, based on the Akaike Information Criterion, with estimates of half-life for Acácia, Capoeira, and Sabiá soils at 25, 44, and 51 days, respectively. The Stanford and Smith and Juma nonlinear models satisfactorily described the carbon mineralization of soils of all treatments.

Keywords: Nutrient cycling. Carbon dioxide. Forest soil.

\section{Introduction}

Forest sustainability is related to nutrient cycling in order to enhance their return to the trees, with the accumulated litter being an important source of nutrients for the trees in the forest ecosystem, because as the leaves, branches and roots are incorporated into the litter and undergo the decomposition process, they release nutrients to the soil and, consequently, are available to trees (BARRETO et al., 2010; GODINHO et al., 2014). In addition, planting tree species is an alternative for recovering degraded areas (NUNES et al., 2016), however, little is known about natural ecosystems and nutrient cycling in native forests and forest plantations in Brazil (GODINHO et al., 2014; MORAIS et al., 2017).

1 Universidade Federal de Lavras/UFLA. Doutorando em Estatística e Experimentação Agropecuária. Lavras, Minas Gerais, Brasil. edilsonmg3@hotmail.com. Departamento de Estatística, Caixa Postal 37, Campus Universitário da UFLA, Lavras, Minas Gerais, CEP 37200-000. 
The greater amount of organic matter and the presence of easily decomposing substances favor carbon mineralization at the beginning of the process, that is, the decomposition dynamics occur at decreasing rates, as the organic material is mineralized (PULROLNIK, 2009; MOREIRA; SIQUEIRA, 2006), consequently, the release of other nutrients to the soil occurs. These processes can be described by nonlinear models (PAULA et al., 2019; PEREIRA; MUNIZ; SILVA, 2005; SILVA et al., 2019a; SILVA et al., 2019b; ZEVIANI et al., 2012; OLIVEIRA et al., 2013). The knowledge of the carbon (C) mineralization dynamics in the soil is essential for the development of appropriate practices in the soil use, being indicative of the organic residues contributing to the demand of trees throughout the crop cycle (BARRETO et al., 2010; GODINHO et al., 2014).

The nonlinear model most used to describe the dynamics of carbon in the soil is Stanford and Smith (ANDRADE; ANDREAZZA; CAMARGO, 2016; ANDRADE et al., 2015), including litter decomposition data (BARRETO et al., 2010; NUNES et al., 2016). It is a model with two parameters that represent the potentially mineralizable carbon and the mineralization constant. Another model used is the nonlinear Juma (PAULA et al. , 2019; PEREIRA; MUNIZ; SILVA, 2005) with two parameters that present direct practical interpretation, potentially mineralizable carbon, and half-life, respectively. In litter soils, it may be that the mineralization process has two phases of mineralization, one phase due to easily mineralizable substances and another phase due to the more resistant substances. In processes with two phases, the use of the Cabrera model has shown a good fit (PAULA et al., 2019; SILVA et al., 2019a; SILVA et al., 2019b; ZEVIANI et al., 2012; PEREIRA et al., 2009).

The objective of the study was to describe the dynamics of carbon mineralization in litter soils using the nonlinear models Stanford and Smith (1972), Juma, Paul and Mary (1984) and Cabrera (1993), indicating the most appropriate model and, also, estimating potentially mineralizable carbon and half-life times.

\section{Material and methods}

Data used to fit the models were extracted from Nunes, Rodrigues and Rodrigues (2009) and correspond to the average results of an experiment with a Red Yellow Latosol in the municipality of Conceição de Macabu, state of Rio de Janeiro, which evaluated the soil carbon mineralization under three types of forest cover: Atlantic forest fragment (capoeira), Acacia auriculiformis trees (acacia) and Mimosa caesalpiniifolia (sabiá) from a reforested area with a history of degradation.

The evaluated soil was collected in the interrow at a layer $0-10 \mathrm{~cm}$ deep, samples were duplicated, using $50 \mathrm{~g}$ each soil. Samples were incubated in percolation columns constructed with PVC tubes (29.4 cm in height and $4.7 \mathrm{~cm}$ in diameter). Carbon mineralization was assessed by $\mathrm{CO}_{2}$ emission during incubation. The released $\mathrm{CO}_{2}$ was captured in $10 \mathrm{~mL}$ of a $1 \mathrm{~mol} \mathrm{~L}^{-1} \mathrm{NaOH}$ solution, the excess of which was titrated with a $0.5 \mathrm{~mol} \mathrm{~L}^{-1} \mathrm{HCl}$ solution. In litter soil samples, mineralized carbon was always measured in the same experimental units at $6,12,18,25,38,53,84,112$, $138,168,194$, and 222 days from the beginning of the incubation.

Stanford and Smith models were evaluated:

$$
C_{i}=C_{0}\left(1-\exp \left(-k t_{i}\right)\right)+\varepsilon_{i}
$$


Juma:

$$
C_{i}=\frac{C_{0} t_{i}}{t_{1 / 2}+t_{i}}+\varepsilon_{i}
$$

Cabrera:

$$
C_{i}=C_{1}\left(1-\exp \left(-k_{1} t_{i}\right)\right)+k_{0} t_{i}+\varepsilon_{i}
$$

In the models, $\mathrm{C}_{\mathrm{i}}$ is the mineralized carbon, in $\mathrm{mg} \mathrm{CO}_{2} \mathrm{~kg}^{-1}$, until time $\mathrm{t}_{\mathrm{i}}$ (in days); $\mathrm{C}_{0}$ is the fraction of organic carbon susceptible to mineralization; $\mathrm{k}, \mathrm{k}_{1}$, and $\mathrm{k}_{0}$ are mineralization constants; $t_{1 / 2}$ is the half-life of the potentially mineralizable carbon; $C_{1}$ is the fraction of easily mineralizable organic carbon and is the experimental error with normal distribution with mean 0 and variance $\sigma^{2}$. The half-life $\left(\mathrm{t}_{1 / 2}\right)$ of the Stanford and Smith and Cabrera models were estimated by $t_{1 / 2}=\ln (2) / \mathrm{k}$ and $\mathrm{t}_{1 / 2}=\ln (2) / \mathrm{k}_{1}$, respectively (ZEVIANI et al., 2012).

Tests applied to check the assumptions of the regression models: Shapiro-Wilk, to check the assumption of error normality; Breusch-Pagan, to test the hypothesis that the errors are homoscedastic and the Durbin-Watson test, to check the independence of the errors. When the Durbin-Watson test rejected the null hypothesis that the experimental errors were independent, the model errors were considered as follows: $\varepsilon_{t}=\varphi \varepsilon_{t-1}+\lambda_{t}$, at which $\varphi$ is the first-order autocorrelation parameter $\operatorname{AR}(1)$ and $\lambda_{t}$ is white noise (MORETTIN; TOLOI, 2006; SAVIAN; MUNIZ, 2007; PRADO; SAVIAN; MUNIZ, 2013; SOUSA et al., 2014; MUIANGA et al., 2016; MUNIZ; NASCIMENTO; FERNANDES, 2017 ; RIBEIRO et al., 2018a; JANE, et al., 2020; PRADO et al., 2020). In cases in which the assumption of normality was met, the confidence interval was estimated with a $95 \%$ probability for the model parameters based on the expression:

$$
\operatorname{IC}(\theta) \Rightarrow \hat{\theta}_{i} \pm \mathrm{t}_{(\mathrm{q} ; 0,025)} \mathrm{S}\left(\hat{\theta}_{i}\right)
$$

at which: is the estimate of the model parameter; $\mathrm{t}_{(\mathrm{q} ; 0.025)}$ is the value in the t-Student distribution with $\mathrm{q}=\mathrm{n}-\mathrm{p}$ degrees of freedom and area of 0.025 to the right; $S\left(\hat{\theta}_{i}\right)$ is the standard error of the estimate of the parameter $\hat{\theta}_{i}$, obtained by the square root of the corresponding term on the diagonal of the estimated variance and covariance matrix (DRAPER; SMITH, 2014).

The goodness of fit was assessed by the adjusted coefficient of determination:

$$
R_{a j}^{2}=1-\frac{(n-i)\left(1-R^{2}\right)}{n-p}
$$

And by residual standard deviation:

$$
D P R=\sqrt{Q M E}
$$


The selection of the best model was made based on Akaike's information criterion:

$$
A / C=-2 \ln L(\hat{\theta})+2 p .
$$

In the expressions, $\mathrm{n}$ is the number of observations used to fit the model; $\mathrm{i}$ is related to the intercept of the model, which is equal to 1 if there is an intercept and 0 if not, $p$ is the number of parameters; $R^{2}=1-\frac{S S E}{S Q T}$ is the coefficient of determination, with SSE being the sum of squares of errors,

SST being the sum of squares of the total, $M S E=\frac{S S E}{n-p^{\prime}}$ the mean square of the error; $\ln L(\hat{\theta})$ is the value of the natural logarithm of the likelihood function, considering parameter estimates.

Estimation of parameters of nonlinear regression models was done approximately way by iterative numerical methods, as there is no closed way to solve the system of normal equations. Among the iterative methods, the Gauss-Newton method is the most used (PEREIRA; MUNIZ; SILVA, 2005; FERNANDES et al., 2015; FERNANDES; PEREIRA; MUNIZ, 2017; SILVEIRA et al., 2018; RIBEIRO et al., 2018b; JANE, et al., 2019; SILVA et al., 2019c; SILVA et al., 2019d). Parameters were estimated using the generalized least squares method, implemented in the gnls function, from the nlme package (PINHEIRO et al., 2015), in R software (R DEVELOPMENT CORE TEAM, 2015).

\section{Results and discussion}

The Cabrera model did not fit any treatment, since the confidence intervals for at least one parameter included a value of zero, indicating that the treatments did not have two mineralizable carbon compartments. Thus, the results for this model were not presented in the following tables. In fitting the Molina model (double exponential) to $\mathrm{C}$ mineralization data from soil under eucalyptus plantation, Barreto et al. (2010) obtained non-significant parameters for the model, thus indicating that the process did not have two carbon compartments. On the other hand, Silva et al. (2019a) reported two phases of carbon mineralization of the treatments soil + oat straw, soil + pig slurry, and soil + pig slurry + oat straw, in addition, Silva et al. (2019b) observed the same behavior for soil + sewage sludge + oat straw.

Table 1 lists the results of the analysis of errors estimated by the Stanford and Smith and Juma models, based on carbon mineralization data in litter soil for the Shapiro-Wilk (SW), Breusch-Pagan (BP), and Durbin-Watson (DW) tests. For all treatments and both models, the SW test was not significant ( $p$-value $>0.05$ ), thus the assumption of error normality was corroborated by the test. The BP test evidenced that the hypothesis of homogeneity of variances was not rejected ( $p$-value $>0.05$ ) for all treatments and both models, indicating that the residual variance was homogeneous. The DW test indicated that for all treatments and both models the errors were independent ( $p$-value $>0.05$ ), except for the Juma model fit to the Acacia soil treatment ( $p$-value $<0.05)$. The independence of errors was rejected for this treatment because the measurements were made in the same experimental unit, so the parameter $\varphi$ was added to explain this correlation (TABLE 3), that is, for this treatment an adjustment with first-order auto-regressive error AR (1). Silva et al. (2019a), Silva et al. (2019b), and Hess and Schmidt (1995) also observed a correlation in errors when fitting nonlinear models to cumulative data of $\mathrm{CO}_{2}$ mineralization of various organic residues in the soil. 
Table 1 - P-values of the Shapiro-Wilk (SW), Durbin-Watson (DW), and Breusch-Pagan (BP) tests applied to errors of the models and goodness of fit evaluators, adjusted coefficient of determination $\left(R_{a j}{ }^{2}\right)$, residual standard deviation (RSD), and Akaike's information criterion (AIC) for mineralized carbon, for treatments.

\begin{tabular}{|c|c|c|c|c|c|c|c|}
\hline Treatments & Model & $\begin{array}{c}\text { SW } \\
\text { p-value }\end{array}$ & $\begin{array}{c}\text { DW } \\
\text { p-value }\end{array}$ & $\begin{array}{c}\text { BP } \\
\text { p-value }\end{array}$ & Raj2 & RSD & AIC \\
\hline \multirow{2}{*}{ Acácia } & $\begin{array}{l}\text { Stanford } \\
\text { and Smith }\end{array}$ & 0.5489 & 0.3620 & 0.2516 & 0.9887 & 21.53 & 120.52 \\
\hline & Juma & 0.7665 & 0.0060 & 0.1790 & 0.9690 & 33.61 & 130.28 \\
\hline \multirow[t]{2}{*}{ Capoeira } & $\begin{array}{l}\text { Stanford } \\
\text { and Smith }\end{array}$ & 0.4174 & 0.9540 & 0.1371 & 0.9947 & 19.86 & 118.42 \\
\hline & Juma & 0.9507 & 0.3700 & 0.7260 & 0.9921 & 23.58 & 122.89 \\
\hline \multirow[t]{2}{*}{ Sabiá } & $\begin{array}{c}\text { Stanford } \\
\text { and Smith }\end{array}$ & 0.7716 & 0.7100 & 0.7228 & 0.9827 & 35.17 & 133.28 \\
\hline & Juma & 0.9561 & 0.2400 & 0.4232 & 0.9744 & 42.48 & 138.19 \\
\hline
\end{tabular}

Source: Elaborated by the authors (2020).

Estimates of parameters of the Stanford and Smith model and the half-life $\left(\mathrm{t}_{1 / 2}\right)$ with their respective $95 \%$ confidence intervals are listed in Table 2 . It can be seen from the confidence intervals that all model parameters did not include the zero value, indicating that they are significant for all treatments.

Table 2 - Estimates for the parameters of the Stanford and Smith model fitted to the mineralized carbon of the treatments, half-life $\left(t_{1 / 2}\right)$, and their respective $95 \%$ asymptotic confidence intervals ( $L L$ - lower limit and UL upper limit).

\begin{tabular}{cccc}
\hline Parameters & LL & Estimates & UL \\
\hline $\mathbf{C}_{0}$ & 546.1478 & Acácia & \\
$\mathbf{k}$ & 0.0238 & 569.0000 & 592.9476 \\
$\mathbf{t}_{1 / 2}$ & 22.1198 & 0.0273 & 0.0313 \\
& & 25.3714 & 29.1238 \\
$\mathbf{C}_{0}$ & 737.3757 & Capoeira & \\
$\mathbf{k}$ & 0.0137 & 770.00000 & 806.7935 \\
$\mathbf{t}_{1 / 2}$ & 39.3609 & 0.0156 & 0.0176 \\
& & 44.3472 & 50.2644 \\
$\mathbf{C}_{0}$ & 722.6286 & Sabiá & \\
$\mathbf{k}$ & 0.0106 & 785.7000 & 867.2678 \\
$\mathbf{t}_{1 / 2}$ & 41.4066 & 0.0135 & 0.0167 \\
\hline
\end{tabular}

Source: Elaborated by the authors (2020).

Considering the confidence intervals of $\mathrm{C}_{0}$ of litter soils, there was no overlap between the Acácia soil and the Capoeira, and Sabiá soils, thus indicating that the potentially mineralizable carbon of this treatment was lower than that of the two treatments (TABLE 2). A similar result was obtained for $t_{1 / 2}$. The half-lives of the Acácia, Capoeira and Sabiá soils considering the Stanford and Smith 
model were approximately 25,44 , and 51 days, and the potential mineralizable carbon estimated at 569,770 and $785 \mathrm{mg} \mathrm{CO}_{2} \mathrm{~kg}^{-1}$, respectively.

Table 3 lists the estimates of parameters of the Juma model with their respective $95 \%$ confidence intervals.

Table 3 - Estimates for the parameters of the Juma model fitted to the mineralized carbon of treatments and their respective 95\% asymptotic confidence intervals (LL - lower limit and UL - upper limit).

\begin{tabular}{cccc}
\hline Parameters & LL & Estimates & UL \\
\hline $\mathbf{C}_{0}$ & 585.2125 & Acácia & \\
$\mathbf{t}_{1 / 2}$ & 18.8531 & 669.3164 & 453.4202 \\
$\varphi$ & & 33.3629 & \\
& & 0.5225 & \\
$\mathbf{C}_{0}$ & 943.9254 & Capoeira & 1109.4929 \\
$\mathbf{t}_{1 / 2}$ & 59.5298 & 1019.3420 & 89.5100 \\
& & 72.7270 & \\
$\mathbf{C}_{0}$ & 932.3150 & Sabiá & 1305.0996 \\
$\mathbf{t}_{1 / 2}$ & 63.4984 & 1084.1800 & 136.6673 \\
\hline
\end{tabular}

Source: Elaborated by the authors (2020).

By the confidence interval of $C_{0}$ (TABLE 3), it was obtained a lower amount of potentially mineralizable carbon for the Acácia treatment in relation to the Capoeira and Sabiá treatments, as there was no overlap of the confidence intervals. The $t_{1 / 2}$ was estimated at approximately 33, 72, and 91 days for the treatments Acácia, Capoeira, and Sabiá, respectively.

Comparing the ranges (upper limit - lower limit) of the confidence intervals of the parameters $\mathrm{C}_{0}$ and $\mathrm{t}_{1 / 2}$ of the Juma model (TABLE 3 ) and the Stanford and Smith model (TABLE 2), it is observed that for all treatments the range of parameters of the Juma model was wider, so the intervals of the estimates were less accurate. In addition, comparing the confidence intervals of $\mathrm{C}_{0}$ from the Stanford and Smith model (TABLE 2) with those of the Juma model (TABLE 3), it can be seen that the Juma model estimated a higher amount of potentially mineralizable carbon than the Stanford and Smith model, as there was no overlap in the intervals, except for the Acacia treatment. Thus, it is important to emphasize that the variation observed in the estimates of $C_{0}$ and $t_{1 / 2}$ in the different models is due to peculiarities of the statistical models (ZEVIANI et al., 2012).

For both adjusted models, $\mathrm{R}_{\mathrm{aj}}{ }^{2}$ values greater than $96 \%$ were obtained (TABLE 1 ) indicating a good fit of the models to the data, as it can be seen in Figure 1, in addition to the close values of residual standard deviation (RSD) for both models being smaller for the Stanford and Smith model. Thus, the two models were suitable to describe carbon mineralization in soil. As lower AIC values (TABLE 1) were obtained for all treatments with the Stanford and Smith model, this model proved to be more suitable for describing all treatments under study. 
Figure 1 - Stanford and Smith and Juma models fitted to the mineralized $\mathrm{CO}_{2}$ accumulated during soil incubation under Acácia, Sabiá, and Capoeira stand.

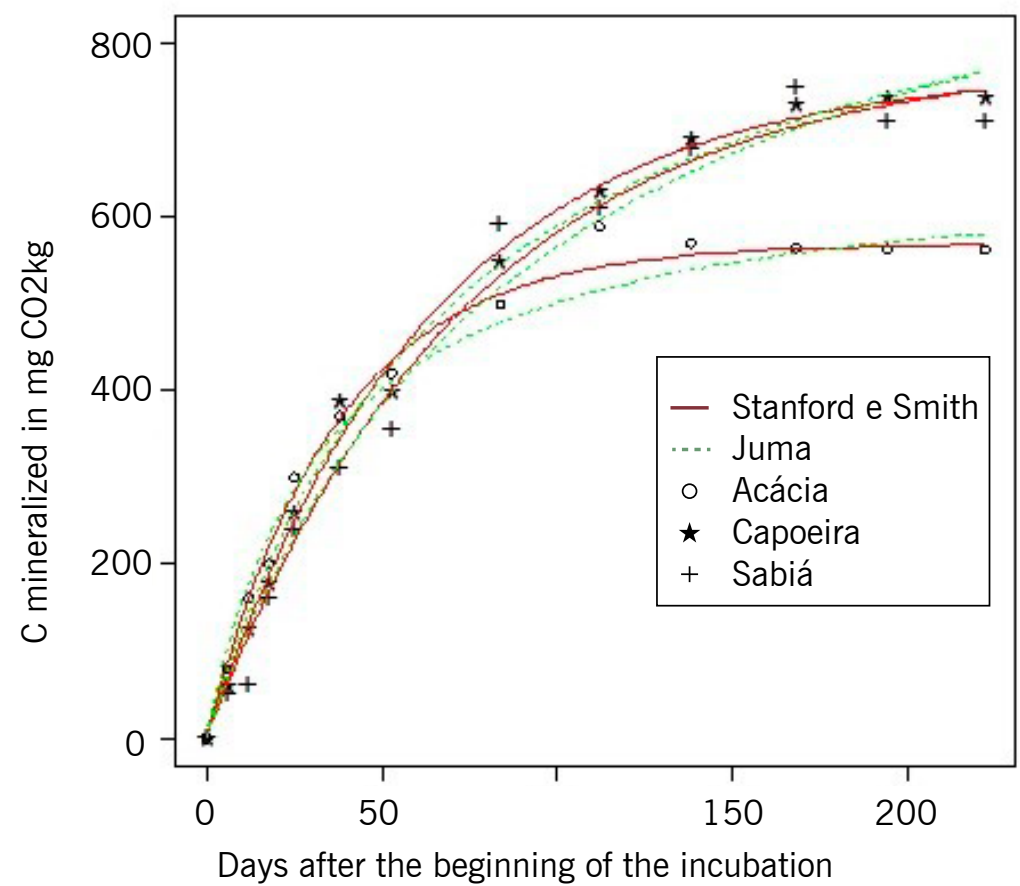

Source: Elaborated by the authors (2020).

\section{Conclusion}

Stanford and Smith and Juma nonlinear models adequately described the carbon mineralization process of litter soils. The Stanford and Smith model was the most suitable in describing all treatments with estimates of potentially mineralizable carbon at 569, 770 and $785 \mathrm{mg} \mathrm{CO}_{2} \mathrm{~kg}^{-1}$ and half-lives of 25, 44 and 51 days of the Acácia, Capoeira and Sabiá, respectively. The Acacia soil obtained a smaller amount of potentially mineralizable carbon than the Capoeira and Sabiá soils.

\section{Acknowledgments}

The authors thank the Conselho Nacional de Desenvolvimento Científico e Tecnológico (CNPq), Coordenação de Aperfeiçoamento de Pessoal de Nível Superior (CAPES) and Instituto de Bolsas de Estudos de Moçambique (IBE).

\section{Comparação de modelos não lineares na descrição da mineralização de carbono em solo de serapilheira}

\section{Resumo}

A serapilheira é uma importante fonte de nutrientes para as árvores e pode melhorar a qualidade dos solos degradados. 0 objetivo deste trabalho foi descrever a dinâmica de mineralização do carbono em solos de serapilheiras por modelos não lineares, estimando os tempos de meia-vida. Foi avaliada a 
mineralização de carbono de solo sob três coberturas florestais: fragmento florestal de mata atlântica (capoeira), espécies arbóreas de Acacia auriculiformis (acácia) e Mimosa caesalpiniifolia (sabiá) de área reflorestada com histórico de degradação. Foram feitas 12 medidas do carbono mineralizado até os 222 dias do início da incubação de solos de serapilheira. Foram ajustados os modelos Stanford e Smith, Juma e Cabrera, pelo método de mínimos quadrados utilizando o algoritmo de Gauss-Newton por meio do software R. O modelo Stanford e Smith foi mais adequado na descrição de todos os tratamentos, com base no Critério de Informação de Akaike com estimativas dos tempos de meia-vida dos solos de Acácia, de Capoeira e de Sabiá de 25, 44 e 51 dias, respectivamente. Os modelos não lineares Stanford e Smith e Juma descreveram de forma satisfatória a mineralização do carbono dos solos de todos os tratamentos.

Palavras-chave: Ciclagem de nutrientes. Dióxido de carbono. Solo florestal.

\section{References}

ANDRADE, C. A.; BIBAR, M. P. S.; COSCIONE, A. R.; PIRES, A. M. M.; SOARES, A. G. Mineralization and effects of poultry litter biochar on soil cation exchange capacity. Pesquisa Agropecuária Brasileira, v. 50, n. 5, p. 407-416, 2015. Available at: http://www.scielo.br/scielo.php?script=sci arttext\&pid=S0100-204X2015000500407. Access on: 13 maio 2019. DOI: http://dx.DOI.org/10.1590/ s0100-204X2015000500008.

ANDRADE, L. C.; ANDREAZZA, R.; CAMARGO, F. A. O. Soil microbial activity under wastewater treatment plant sludge doses from an industrial landfill. Ciência Rural, v. 46, n. 2, p. 267-272, 2016. Available at: http://www.scielo.br/scielo.php?script=sci_arttext\&pid=S0103-84782016000200267. Access on: 13 maio 2019. DOI: http://dx.DOI.org/10.1590/0103-8478cr20140871.

BARReto, P. A. B.; ROdRIGUES, E. F. G.; ROdRIGUES, A. C. G.; BARROS, N. F.; AlVES, B. J. R.; FONSECA, S. Carbon and nitrogen mineralization in soils under an eucalyptus plantation chronosequence. Revista Brasileira de Ciência do Solo, v. 34, p. 735-745, 2010. Available at: http://www.scielo.br/ scielo.php?script=sci_arttext\&pid=S0100-06832010000300015. Access on: 13 maio 2019. DOI: http://dx.DOI.org/10.1590/S0100-06832010000300015.

CABRERA, M. L. Modeling the flush of nitrogen mineralization caused by drying and rewetting soils. Soil Science Society of America Journal, v. 57, p. 63-66, 1993.

DRAPER, N. R.; SMITH, H. Aplied regression analisys, $3^{\text {rd }}$ ed, reprint, New York: J. Wiley, 2014.

FERNANDES, T. J.; MUNIZ, J. A.; PEREIRA, A. A.; MUNIZ, F. R.; MUIANGA, C. A. Parameterization effects in nonlinear models to describe growth curves. Acta Scientiarum. Technology, v. 37, n. 4, p. 397-402, 2015. Available at: https://www.researchgate.net/publication/283735241_Parameterization_effects_ in_nonlinear_models_to_describe_growth_curves. Access on: 30 set. 2019.

FERNANDES, T. J.; PEREIRA, A. A.; MUNIZ, J. A. Double sigmoidal models describing the growth of coffee berries. Ciência Rural, v. 47, n. 8, p. 1-7, 2017. Available at: http://www.scielo.br/scielo.php? script=sci_arttext\&pid=S0103-84782017000800401. Access on: 30 set. 2019. 
GODINHO, T. O.; CALDEIRA, M. V. W.; ROCHA, J. H. T.; CALIMAN, J. P.; TRAZZI, P. A. Quantification of biomass and nutrients in the accumated litter in a section of submontane seasonal semideciduous forest, ES. Cerne, v. 20, n. 1, p. 11-20, 2014. Available at: http://www.scielo.br/scielo.php?script=sci_ arttext\&pid=S0104-77602014000100002. Access on: 13 maio 2019. DOI: http://dx.DOI.org/10.1590/ S0104-77602014000100002.

HESS, T. F.; SCHMIDT, S. K. Improved procedure for obtaining statistically valid parameter estimates from soil respiration data. Soil Biology and Biochemistry, Elmsford, v.27, p. 1-7, 1995. Available at: https://www.sciencedirect.com/science/article/abs/pii/003807179400166X?via\%3Dihub. Access on: 13 maio 2019. DOI: https://DOI.org/10.1016/0038-0717(94)00166-X.

JANE, S. A.; FERNANDES, F. A.; SILVA, E. M.; MUNIZ, J. A.; FERNANDES, T. J. Comparison of the polynomial and nonlinear models on description of pepper growth. Revista Brasileira de Ciências Agrárias, v. 14, n.4, p. 1-7, 2019. Available at: https://www.researchgate.net/publication/337935579_ Recife_v14_n4_e7180. Access on: 13 maio 2019.

JANE, S. A.; FERNANDES, F. A.; SILVA, E. M.; MUNIZ, J. A.; FERNANDES, T. J.; PIMENTEL, G. V. Adjustment of growth curve of different sugarcane varieties using nonlinear models. Ciência Rural, v. 50, n.3, p. 1-10, 2020. Available at: https://www.scielo.br/scielo.php?pid=S0103-84782020000300204\&script=sci_ arttext\&tlng=en . Access on: 13 maio 2019.

JUMA, N. G., PAUL, E. A.; MARY, B. Kinetic analysis of net mineralization in soil. Soil Science Society of America Journal, v. 48, p. 465-472, 1984.

MORAIS, V. A.; SANTOS, C. A.; MELLO, J. M.; DADID, H. C.; ARAÚJO, E. J. G.; SCOLFORO, J. R. S. Spatial and vertical distribution of litter and belowground carbon in a brazilian cerrado vegetation. Cerne, v. 23, n. 1, p. 43-52, 2017. Available at: http://www.scielo.br/scielo.php?script=sci_ arttext\&pid=S0104-77602017000100043. Access on: 13 maio 2019. DOI: http://dx.DOI.org/ 10.1590/01047760201723012247.

MOREIRA, F. M. S, SIQUEIRA, J. O. Microbiologia e Bioquímica do solo. 2. ed. Lavras: Editora da UFLA, p. 1-729, 2006.

MORETTIN, P. A.; TOLOI, C. M. C. Análise de séries temporais, 2. ed. São Paulo: Edgard Blucher, 2006.

MUIANGA, C. A.; MUNIZ, J. A.; NASCIMENTO, M. S.; FERNANDES, T. J.; SAVIAN, T. V. Descrição da curva de crescimento de frutos do cajueiro por modelos não lineares. Revista Brasileira de Fruticultura, $v$. 38, n. 1, p. 22-32, 2016. Available at: http://www.scielo.br/scielo.php?script=sci_arttext\&pid=S0100$29452016000100022 \&$ Ing $=$ en\&nrm=iso\&tlng=pt. Access on: 30 set. 2019.

MUNIZ, J. A.; NASCIMENTO, M. S.; FERNANDES, T. J. Nonlinear models for description of cacao fruit growth with assumption violations. Revista Caatinga, v. 30, n. 1, p. 250-257, 2017. Available at: http://www.scielo.br/scielo.php?script=sci_arttext\&pid=S1983-21252017000100250 Access on: 30 set. 2019. 
NUnes, D. A. D.; ROdRIGUES, E. F. G.; BARRetO, P. A. B.; RODRIGUES, A. C. G.; MONROE, P. H. M. Carbon and nitrogen mineralization in soil of leguminous trees in a degraded pasture in northern Rio de Janeiro, Brazil. Journal of Forest Research, n. 27, p. 91-99, 2016. Available at: https://www.researchgate.net/publication/283081169_Carbon_and_nitrogen_mineralization_in_soil_ of_leguminous_trees_in_a_degraded_pasture_in_northern_Rio_de_Janeiro_Brazil. Access on: 13 maio 2019. DOI: 10.1007/s11676-015-0164-3.

NUNES, D. A. D.; RODRIGUES, E. F. G.; RODRIGUES, A. C. G. Mineralization of C in soil and non-litter addition of plant under different coverage. Revista Brasileira de Agroecologia, v. 4, n. 2, p. 2176-2179, 2009. Available at: http://revistas.aba-agroecologia.org.br/index.php/rbagroecologia/ article/view/7912/5656. Access on: 30 set. 2019.

OLIVEIRA, W. J.; SILVA, C. A.; MUNIZ, J. A.; SAVIAN, T. V. Nitrogen mineralization in latosols fertilized with organic residues. Revista Brasileira de Ciência do Solo, v. 37, n. 3, p. 715-725, 2013. Available at: http://www.scielo.br/scielo.php?pid=S0100-06832013000300018\&script=sci_abstract . Access on: 06 set. 2019.

PAULA, G. S.; SILVA, E. M.; FURTADO, T. D. R.; FRUHAUF, A. C.; MUNIZ, J. A. Comparison of nonlinear models for the description of carbon mineralization in soils treated with pig slurry. Revista Agrogeoambiental, v. 11, n. 4, p. 82-95, 2019. Available at: https://agrogeoambiental.ifsuldeminas. edu.br/index.php/Agrogeoambiental/article/view/1412. Access on: 10 out. 2019. DOI: http://dx.doi.org/ 10.18406/2316-1817v11n420191412.

PEREIRA, J. M.; MUNIZ, J. A.; SILVA, C. A. Nonlinear models to predict nitrogen mineralization in an oxisol. Scientia Agricola, v. 62, p. 395-400, 2005. Available at: http://www.scielo.br/scielo.php?script=sci arttext\&pid=S0103-90162005000400014 . Access on: 13 maio 2019. DOI: http://dx.DOI.org/10.1590/ S0103-90162005000400014.

PEREIRA, J. M.; MUNIZ, J. A.; SÁFADI, T.; SILVA, C. A. Comparison of the models for prediction of the mineralized nitrogen: a Bayesian approach. Ciência e Agrotecnologia, v. 33, p. 1792-1797, 2009. Available at: http://www.scielo.br/scielo.php?script=sci_arttext\&pid=S141370542009000700016\&Ing=en\&nrm=iso\&tIng=pt. Access on: 30 set. 2019.

PINHEIRO, J.; BATES, D.; DEBROY, S.; SARKAR, D. nlme: linear and nonlinear mixed effects models. R package version 3. p. 1-122. 2015. URL: http://CRAN.R-project.org/package=nlme. Access on: 10 fev. 2019.

PRADO, T.K.L. do; SAVIAN, T.V.; FERNANDES, T.J.; MUNIZ, J.A. Study of the growth curve of the internal cavity of fruit dwarf green coconut. Revista Ciência Agronômica, v. 51, n.3, p. 1-7, 2020. Available at: https://www.scielo.br/scielo.php?script=sci_arttext\&pid=S1806-66902020000300401\&lng=en\&n rm=iso\&tlng=en. Access on: 10 out. 2020. DOI: https://doi.org/10.5935/1806-6690.20200041.

PRADO, T. K. L.; SAVIAN, T. V.; MUNIZ, J. A. Ajuste dos modelos Gompertz e Logístico aos dados de crescimento de frutos de coqueiro anão verde. Ciência Rural, v. 43, n. 5, p. 803-809, 2013. Available at: http://www.scielo.br/pdf/cr/v43n5/a13313cr5976.pdf Access on: 30 set. 2019. 
PULROLNIK, K. Transformações do carbono no solo. 1. ed. Planaltina, DF: Embrapa Cerrados, 2009.

R DEVELOPMENT CORE TEAM. R: a language and environment for statistical computing. R Foundation for Statistical Computing, Vienna, 2015.

RIBEIRO, T. D.; MATTOS, R. W. P.; MORAIS, A. R.; MUNIZ, J. A. Description of the growth of Pequi fruits by nonlinear models. Revista Brasileira de Fruticultura, v. 40, n. 4, p. 1-11, 2018 a. Available at: http://www.scielo.br/scielo.php?script=sci_arttext\&pid=S0100-29452018000400705. Access on: 20 dez. 2019.

RIBEIRO, T. D.; SAVIAN, T. V.; FERNANDES, T. J.; MUNIZ, J. A. The use of the nonlinear models in the growth of pears of "Shinseiki" cultivar. Ciência Rural, v. 48, n. 1, p. 1-7, 2018b. Available at: http://www. scielo.br/scielo.php?script=sci_arttext\&pid=S0103-84782018000100202. Access on: 20 dez. 2019.

SAVIAN, T. V.; MUNIZ, J. A. A study of in situ degradability: heterogeneity of variances and correlated errors. Scientia Agricola, v. 64, n. 5, p. 548-554, 2007. Available at: http://www.scielo.br/scielo. php?script=sci_arttext\&pid=S0103-90162007000500013. Access on: 30 set. 2019 .

SILVA, E. M.; FURTADO, T. D. R.; FERNANDES, J. G. F.; MUNIZ, J. A. Description of the carbon mineralization of swine manure and oat straw in the soil through nonlinear models. Revista Agrogeoambiental, v. 11, n. 2, p. 71-86, 2019a. Available at: https://agrogeoambiental.ifsuldeminas. edu.br/index.php/Agrogeoambiental/article/view/1299/pdf. Access on: 30 set. 2019.

SILVA, E. M.; SILVEIRA, S. C.; FURTADO, T. D. R.; MUNIZ, J. A. Fitting of decomposition of sewage sludge and oat straw by nonlinear models. Revista Agrogeoambiental, v. 11, n. 2, p. 18-28, 2019b. Available at: https://agrogeoambiental.ifsuldeminas.edu.br/index.php/Agrogeoambiental/article/ view/1287/pdf. Access on: 30 set. 2019.

SILVA, E. M.; FRUHAUF, A. C.; FERNANDES, F. A.; PAULA, G. S.; MUNIZ, J. A.; FERNANDES, T. J. Método de Newton e Gauss-Newton na estimação dos parâmetros de modelo de regressão não linear. Sigmae, v. 8, n. 2, p. 728-734, 2019c. Available at: https://publicacoes.unifal-mg.edu.br/revistas/ index.php/sigmae/article/view/946/692. Access on: 30 set. 2019.

SILVA, E. M.; SILVA, V. F.; FERNANDES, F. A.; MUNIZ, J. A.; FERNANDES, T. J. O crescimento de frutos de pêssegos caracterizados por modelos de regressão não lineares. Sigmae, v. 8, n. 2, p. 290-294, 2019d. Available at: https://publicacoes.unifal-mg.edu.br/revistas/index.php/sigmae/article/ view/958/643. Access on: 30 set. 2019.

SILVEIRA, S. C; MUNIZ, J. A.; SOUSA, F. A.; CAMPOS, A. T. Non-linear models adjusted to the accumulated production of biogas originating from swine deep bedding. Revista Agrogeoambiental, v. 10, n. 3, p. 91-103, 2018. Available at: https://agrogeoambiental.ifsuldeminas.edu.br/index.php/ Agrogeoambiental/article/view/1168/pdf. Access on: 26 nov. 2019.

SOUSA, I. F.; KUNZLE, J. E.; MUNIZ, J. A.; GUIMARÃES, R. M.; SAVIAN, T. V.; MUNIZ, F. R. Fitting nonlinear autoregressive models to describe coffee seed germination. Ciência Rural, v. 44, n. 11, p. 2016-2021, 2014. DOI:10.1590/0103-8478cr20131341. Available at: http://www.scielo.br/ scielo.php?script=sci_arttext\&pid=S0103-84782014001102016 . Access on: 06 set. 2019. 
STANFORD, G.; SMITH, S. J. Nitrogen mineralization potentials of soils. Soil Science Society of America Jornal, v. 36, p. 465-471, 1972.

ZEVIANI, W. M.; SILVA, C. A.; OLIVEIRA, W. J.; MUNIZ, J. A. Non linear models to potassium release from animals manure in latosols. Ciência Rural, v. 42, p. 1789-1796, 2012. Available at: http://www.scielo.br/scielo.php?script=sci_arttext\&pid=S0103-84782012001000012. Access on: 13 maio 2019. DOI: http://dx.DOI.org/10.1590/S0103-84782012001000012.

Received: October 04, 2019

Accepted: June 24, 2020 